\title{
BOOK REVIEW \\ Metode Mendidik Anak dalam Perspekif Islam
}

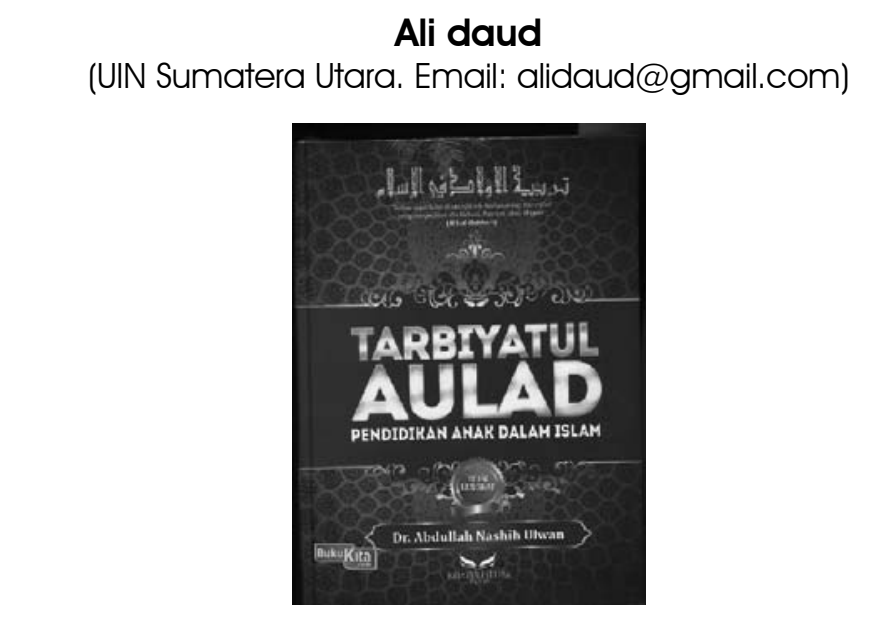

Judul: Tarbiyatul Aulad (Pendidikan Anak Dalam Islam)

Penulis: Dr Abdullah Nashih Ulwan

Halaman: iii +905

Penerbit: Khatulistiwa Publishing, Jakarta

Cetakan: Kedua

Tahun: Dzulhijjah 1436 H, Februari 2015 M

\section{KONSEP PENDIDIKAN MORAL ANAK DALAM KELUARGA}

Dalam buku ini Abdullah Nashih Ulwan menjelaskan bagaimana melaksanakan pendidikan moral anak dalam keluarga agar berhasil dengan syarat harus memenuhi faktor-faktor yang akan dibahas secara rinci dan dalam. Diantara salah satu faktornya adalah harus menggunakan metode yang sesuai dengan perkembangan dan pertumbuhan anak.

Abdullah Nashih Ulwan merupakan salah satu pemikir dan pemerhati pendidikan Islam, terutama pendidikan anak menawarkan kepada para pendidik termasuk orang tua agar dalam memberikan informasi pendidikan moral menggunakan metode yang baik dan sesuai dengan ajaran Rasul SAW.

Buku "Tarbiyatul Aulad Fil Islam" memiliki karakteristik tersendiri. Keunikan karakteristik itu terletak pada uraiannya yang menggambarkan totalitas dan keutamaan Islam. Islam sebagai agama yang tertinggi dan tidak ada yang melebihi ketinggiannya adalah menjadi obsesi Abdullah Nashih Ulwan dalam setiap analisa dan argumentasinya, sehingga tidak ada satu bagian pun dalam kitab tersebut yang 
uraiannya tidak didasarkan atas dasar-dasar dan kaidah-kaidah nash.

Sebagaimana dikemukakan Abdullah Nashih Ulwan bahwa kitab ini disusun dalam tiga bagian atau "qism” yang kronologis, masing-masing bagian memuat beberapa pasal dan setiap pasal mengandung beberapa topik pembahasan. Juduljudul dan pasal-pasal dalam setiap bagian itu akan tersusun sebagai berikut ini: Bagian pertama terdiri dari beberapa pasal, yaitu: Pasal pertama, adalah perkawinan teladan dalam kaitannya dengan pendidikan. Pasal kedua, adalah perasaan psikologis terhadap anak-anak. Pasal ketiga adalah hukum umum dalam hubungannya dengan anak yang lahir.

Abdullah Nashih Ulwan merincikan bukunya dengan urutan sebagai berikut pasal pertama terdiri dari empat bahasan: Pertama adalah yang dilakukan oleh pendidik ketika lahir. Kedua yaitu penamaan anak dan hukumnya. Ketiga adalah aqiqah anak dan hukumnya. Keempat adalah menyunatkan anak dan hukumnya. keempat adalah sebab-sebab kelainan pada anak dan penanggulangannya.

Sedangkan pada bagian kedua Abdullah Nashih Ulwan membagi menjadi yaitu tanggung jawab terbesar bagi para pendidik, bagian ini terdiri dari tujuh pasal adalah sebagai berikut: Pasal pertama adalah tanggung jawab pendidikan Iman. Pasal kedua adalah tanggung jawab pendidikan moral. Pasal ketiga adalah tanggung jawab pendidikan fisik. Pasal keempat adalah tanggung jawab pendidikan intelektual. Pasal kelima adalah tanggung jawab pendidikan psikologis. Pasal keenam adalah tanggung jawab pendidikan sosial. Pasal ketujuh adalah tanggung jawab pendidikan seksual.
Bagian ketiga Abdullah Nashih Ulwan membaginya kepada tiga pasal dan penutup yaitu Pasal pertama, adalah faktor-faktor pendidikan yang berpengaruh. Pasal kedua adalah dasar-dasar fundamental dalam mendidik anak. Pasal ketiga berisi saran-saran paedagogis.

Diantara metode-metode pendidikan moral anak dalam keluarga menurut ulwan adalah pertama, pendidikan dengan keteladanan. Kedua, pendidikan dengan adat kebiasaan. Ketiga, pendidikan dengan nasihat. Keempat, pendidikan dengan memberikan perhatian. Kelima, pendidikan dengan memberikan hukuman.

Menurut pemikiran Ulwan dalam buku Tarbiyatul Aulad menyebutkan bahwa apabila metode-metode tersebut diterapkan dalam pendidikan anak khususnya dalam keluarga, maka secara bertahap mereka para orang tua mempersiapkan anak-anaknya untuk menjadi anggota masyarakat yang berguna bagi kehidupan dan pasukan-pasukan yang kuat untuk kepentingan Islam (sebagai penegak ajaran-ajaran Islam dalam kehidupan).

\section{Metode Pendidikan Moral Anak dalam Keluarga}

Menurut Abdullah Nashih Ulwan sarana untuk membentuk keluarga dalam Islam harus melalui ikatan pernikahan. Dengan melangsungkan pernikahan, maka pasangan suami istri akan memperoleh manfaat dari pernikahan tersebut. Salah satu manfaatnya adalah memelihara kelangsungan jenis manusia di dunia yang fana ini. Kelahiran anak merupakan amanat dari Allah SWT kepada bapak dan ibu sebagai pemegang amanat yang harusnya dijaga, dirawat, dan diberikan pendidikan. Itu semua merupakan bagian dari tanggung jawab orang tua kepada anaknya. 
Anak dilahirkan tidak dalam keadan lengkap dan tidak pula dalam keadaan kosong. Ia dilahirkan dalam keadaan fitrah. Memang ia dilahirkan dalam keadaan tidak tahu apa-apa, akan tetapi anak telah dibekali dengan pendengaran, penglihatan, dan kata hati (Muhammad 'Ali Quthb, 1993: 11).

Dengan diberikannya penglihatan, pendengaran, dan kata hati tersebut, diharapkan orang tua harus mampu membimbing, mengarahkan, dan mendidiknya dengan ekstra hati-hati karena anak sebagai peniru yang ulung. Oleh karena itu semaksimal mungkin orang tua memberikan pelayanan terhadap anaknya. Pelayanan yang maksimal akan menghasilkan suatu harapan bagi bapak ibunya, tiada lain suatu kebahagiaan hasil jerih payahnya. Sebab anak adalah sumber kebahagiaan, kesenangan, dan sebagai harapan dimasa yang akan datang (Muhammad Ali al-Hasyimi, 2000: 250).

Harapan orang tua akan terwujud, tatkala mereka mempersiapkan sedini mungkin pendidikan yang baik sebagai sarana pertumbuhan dan perkembangan bagi anak. Memang diakui bahwa mengemudikan bahtera rumah tangga yang baik, yang sakinah, dan yang maslahah merupakan tugas kewajiban yang sangat rumit, tidak kalah rumitnya dengan mengelola sebuah pabrik, dan tidak kalah canggihnya dengan mengemudikan pesawat terbang karena orang tua harus siap untuk memperpadukan sekian banyak unsur dan dimensi mulai dari dimensi sikap mental, ilmu pengetahuan, ketrampilan dan lain sebagainya. Sebagai kewajiban dari orang tua, dalam hal ini adalah pemegang amanat, maka barang siapa yang mampu menjaga amanat tersebut akan diberi pahala, dan sebaliknya.
Hal ini sesuai dengan janji Allah SWT dalam firmanya, QS.al-Kahfi (18) : 46.

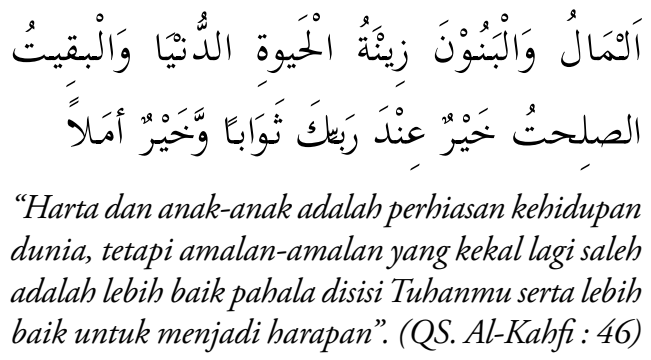

Dalam mendidik anak, tentunya harus ada kesepakatan antara bapak ibu sebagai orang tua, akan dibawa kepada pendidikan yang otoriter atau pendidikan yang demokratis atau bahkan yang liberal, sebab mereka penentu pelaksana dalam keluarga.

Dalam kehidupan masyarakat terkecil, yaitu keluarga, suami secara fungsional adalah penanggung jawab utama rumah tangga (keluarga) sedangkan istri adalah mitra setia yang aktif konstruktif mengelola rumah tangga. Operasionalisasi kehidupan berkeluarga sebaiknya dilakukan berdasarkan amar makruf nahi munkar.

Salah satu wujud amar makruf nahi munkar dalam kehidupan berkeluarga adalah memberikan pendidikan kepada putra putrinya berdasarkan ajaran Islam. Antara keluarga satu dengan keluarga lainnya mempunyai prinsip dan sistem sendiri-sendiri dalam mendidik anaknya. Namun orang tua jangan terbuai atau melupakan terhadap ajaran-ajaran Islam, terutama dalam hal pendidikan anak sebagaimana yang telah dicontohkan Rasul saw. sebagai pembawa panjipanji Islam, Rasul SAW tidak pernah mendidik putra-putrinya dengan pendidikan keras dan tidak dengan membebaskan anak-anaknya, tetapi beliau dalam mendidik keluarganya terutama kepada 
anak-anaknya adalah dengan limpahan kasih sayang yang amat besar.

Senada dengan yang dikatakan oleh sahabat Anas ra. yaitu "aku tidak mendapatkan seseorang yang kasih sayangnya pada keluarganya melebihi Rasulullah SAW. Seorang muslim sepatutunya mencontoh teladan yang telah diberikan Rasul SAW, dalam memuliakan putra putrinya. Beliau dalam mendidik anak-anaknya melalui ajaran wahyu Ilahi yaitu dengan penuh kasih sayang terhadap anakanaknya. Dengan pemberian kasih sayang tersebut, diharapkan dapat menunjang pertumbuhan dan perkembangan anak. Sebab anak merupakan aset masa depan. Sebagai orang tua dapat meneladani ajaran-ajaran Rasul SAW tersebut, melalui para pemikir dan pemerhati pendidikan (anak) dalam Islam. Salah satu pemerhati pendidikan (anak) dalam Islam yang memberikan gambaran yang benar sesuai dengan ajaran Islam adalah Ulwan. Ia memberikan pandangannya dalam mendidik anak dalam keluarga melalui metode-metode yang harus diterapkan dalam pendidikan anak termasuk dalam hal pendidikan moral. Apabila metodemetode tersebut diterapkan, niscaya apa yang menjadi harapan bersama sebagai muslimin yaitu tumbuhnya para generasi Islam yang tangguh dan sebagai penebar kebenaran, dapat direalisasikan.

Untuk memperoleh hasil yang baik dalam pelaksanaan pendidikan (moral) maka harus memenuhi beberapa faktor-faktornya. Salah satu faktornya adalah metode. Metode merupakan sarana untuk menyampaikan isi atau materi pendidikan tersebut, agar tujuan yang diharapkan dapat tercapai dengan hasil yang baik.

Diantara metode pendidikan moral anak dalam keluarga yang ditawarkan oleh Abdullah
Nashih Ulwan adalah: Pertama, Pendidikan dengan keteladanan. Menurut al-Ghazali anak adalah amanat bagi orang tuanya. Hatinya yang suci merupakan permata tak ternilai harganya, masih murni dan belum terbentuk.

Orang tuanya merupakan arsitek atau pengukir kepribadian anaknya. Sebelum mendidik orang lain, sebaiknya orang tua harus mendidik pada dirinya terlebih dahulu. Sebab anak merupakan peniru ulung. Segala informasi yang masuk pada diri anak, baik melalui penglihatan dan pendengaran dari orang di sekitarnya, termasuk orang tua akan membentuk karakter anak tersebut. Apalagi anak yang berumur sekitar 3-6 tahun, ia senantiasa melakukan imitasi terhadap orang yang ia kagumi (ayah dan ibunya). Rasa imitasi dari anak yang begitu besar, sebaiknya membuat orang tua harus ekstra hati-hati dalam bertingkah laku, apalagi didepan anak-anaknya. Sekali orang tua ketahuan berbuat salah dihadapan anak, jangan berharap anak akan menurut apa yang diperintahkan. Oleh karena itu sudah sepantasnya bagi orang tua pemegang amanat, untuk memberikan teladan yang baik kepada putra putrinya dalam kehidupan berkeluarga. Keluarga merupakan sekolah pertama bagi anak. Orang tua terutama ibu merupakan pendidik pertama dan utama bagi anak dalam membentuk pribadinya.

Ibu mempengaruhi anak melalui sifatnya yang menghangatkan, menumbuhkan rasa diterima, dan menanamkan rasa aman pada diri anak. Sedangkan ayah mempengaruhi anaknya melalui sifatnya yang mengembangkan kepribadian, menanamkan disiplin, memberikan arah dan dorongan serta bimbingan agar anak 
tambah berani dalam menghadapi kehidupan (Dr. Abdurrahman 'Isawi, 1994: 35)

Teladan yang baik dari orang tua kepada anak (sekitar umur 6 tahun) akan berpengaruh besar kepada perkembangan anak di masa mendatang. Sebab kebaikan di waktu kanak-kanak awal menjadi dasar untuk pengembangan di masa dewasa kelak. Untuk itu lingkungan keluarga harus sebanyak mungkin memberikan keteladanan bagi anak. Dengan keteladanan akan memudahkan anak untuk menirunya. Sebab keteladanan lebih cepat mempengaruhi tingkah laku anak. Apa yang dilihatnya akan ia tirukan dan lama kelamaan akan menjadi tradisi bagi anak. Hal ini sesuai firman Allah SWT QS. al-Ahzab 33: 21.

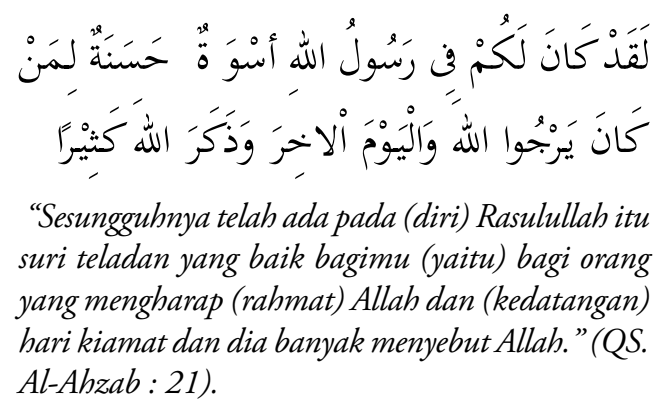

Dalam hal keteladanan ini, lebih jauh Abdullah Nashih Ulwan menafsirkan dalam beberapa bentuk, yaitu pertama, keteladanan dalam ibadah. Kedua, keteladanan bermurah hati. Ketiga, Keteladanan kerendahan hati. Keempat, keteladanan kesantunan. Kelima, keteladanan keberanian. Keenam, keteladanan memegang akidah.

Karena obyeknya anak (kanak-kanak) tentunya bagi orang tua dalam memberikan teladan harus sesuai dengan perkembangannya sehingga anak mudah mencerna apa yang disampaikan oleh bapak ibunya. Sebagai contoh agar anak membiasakan diri dengan ucapan "salam", maka senantiasa orang tua harus memberikan ajaran tersebut setiap hari yaitu hendak pergi dan pulang ke rumah (keteladanan kerendahan hati). Yang penting bagi orang tua tampil dihadapan anak sesuai dengan ajaran-ajaran Islam, niscaya semua itu akan ditirunya.

\section{Pendidikan dengan Pembiasaan}

Setiap manusia yang dilahirkan membawa potensi, salah satunya berupa potensi beragama. Potensi beragama ini dapat terbentuk pada diri anak (manusia) melalui 2 faktor, yaitu: faktor pendidikan Islam yang utama dan faktor pendidikan lingkungan yang baik. Faktor pendidikan Islam yang bertanggung jawab penuh adalah bapak ibunya. Ia merupakan pembentuk karakter anak. Hal ini sesuai dengan sabda Rasul SAW yang diriwayatkan oleh Muslim dan Abu Hurairah. (Imam Muslim, 2012: 2047).

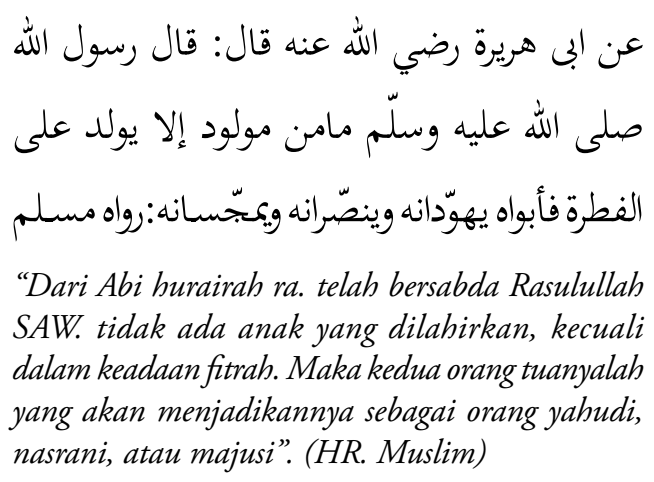

Setelah anak diberikan masalah pengajaran agama sebagai sarana teoritis dari orang tuanya, maka faktor lingkungan harus menunjang terhadap pengajaran tersebut, yakni orang tua senantiasa memberikan aplikasi pembiasaan ajaran agama dalam lingkungan keluarganya. Sebab pembiasaan merupakan upaya praktis dan pembentukan (pembinaan) dan persiapan.

Pada umur kanak-kanak kecenderungannya adalah meniru apa yang dilakukan oleh orang- 
orang disekitarnya, baik saudara famili terdekatnya ataupun bapak ibunya. Oleh karena itu patut menjadi perhatian semua pihak, terutama orang tuanya selaku figur yang terbaik di mata anaknya. Jika orang tua menginginkan putra putrinya tumbuh dengan menyandang kebiasaan-kebiasaan yang baik dan akhlak terpuji serta kepribadian yang sesuai ajaran Islam, maka orang tua harus mendidiknya sedini mungkin dengan moral yang baik. Karena tiada yang lebih utama dari pemberian orang tua kecuali budi pekerti yang baik. Hal ini sesuai dengan sabda Rasul SAW yang diriwayatkan al-Tirmidzi dari Ayyub bin Musa. (Sunan at-Tirmidzi, 2013: 298).

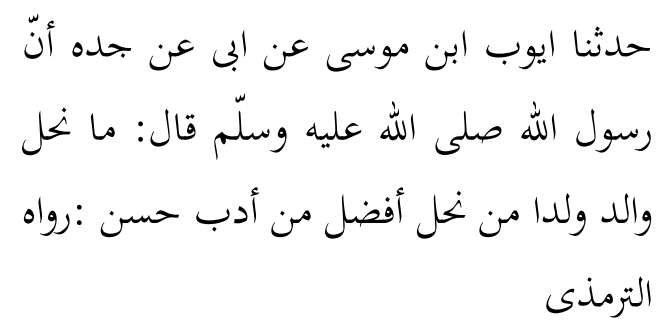

"Diceritakan dari Ayyub bin Musa dari ayahnya dari kakeknya, bahwa Rasulullah saw bersabda : Tidak ada pemberian yang lebih utama dari seorang ayah kepada anaknya kecuali budi pekerti yang baik". (H.R At-Tirmidzi)

Apabila anak dalam lahan yang baik (keluarganya) memperoleh bimbingan, arahan, dan adanya saling menyayangi antar anggota keluarga, niscaya lambat laun anak akan terpengaruh informasi yang ia lihat dan ia dengar dari semua perilaku orang- orang disekitarnya. Dan pengawasan dari orang tua sangat diperlukan sebagai kontrol atas kekeliruan dari perilaku anak yang tak sesuai dengan ajaran Islam.

\section{Pendidikan dengan Nasihat}

Pemberi nasihat seharusnya orang yang berwibawa di mata anak. Dan pemberi nasihat dalam keluarga tentunya orang tuanya sendiri selaku pendidik bagi anak. Anak akan mendengarkan nasihat tersebut, apabila pemberi nasihat juga bisa memberi keteladanan. Sebab nasihat saja tidak cukup bila tidak diikuti dengan keteladanan yang baik.

Anak tidak akan melaksanakan nasihat tersebut apabila didapatinya pemberi nasihat tersebut juga tidak melaksanakannya. Anak tidak butuh segi teoritis saja, tapi segi praktis yang akan mampu memberikan pengaruh bagi diri anak.

Nasihat yang berpengaruh, membuka jalannya ke dalam jiwa secara langsung melalui perasaan. Setiap manusia (anak) selalu membutuhkan nasihat, sebab dalam jiwa terdapat pembawaan itu biasanya tidak tetap, dan oleh karena itu kata-kata atau nasihat harus diulangulang. (Muhammad Quthb, 1993: 334). Nasihat akan berhasil atau mempengaruhi jiwa anak, tatkala orangtua mampu memberikan keadaan yang baik. Hal ini sesuai dengan firman Allah SWT dalam QS. al-Baqarah (2 : 44).

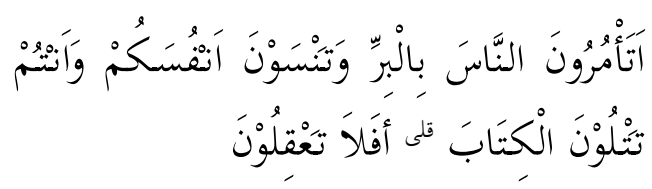

"Mengapa kamu suruh orang lain (mengerjakan) kabaktian, sedang kamu melupakan diri (kewajiban) mu sendiri, Padahal kamu membaca al-Kitab (Taurat)? maka tidakkah kamu berpikir ?(Q.S al-Baqarah : 44)

Agar harapan orang tua terpenuhi yakni anak mengikuti apa-apa yang telah diperintahkan dan yang telah diajarkannya, tentunya disamping memberikan nasihat yang baik juga ditunjang dengan teladan yang baik pula. Karena pembawaan anak mudah terpengaruh oleh kata-kata yang didengarnya dan juga tingkah aku yang sering 
dilihatnya dalam kehidupan sehari-hari dari pagi hari sampai sore hari.

Nasihat juga harus diberikan sesering mungkin kepada anak-anak masa sekolah dasar, sebab anak sudah bersosial dengan teman sebayanya. Agar apa-apa yang telah diberikan dalam keluarganya tidak mudah luntur atau tepengaruh dengan lingkungan barunya.

Menurut Ulwan, dalam Penyajian atau memberikan nasihat itu ada pembagiannya, yaitu: Pertama, menyeru untuk memberikan kepuasan dengan kelembutan atau penolakan. Sebagai contohnya adalah seruan Lukman kepada anakanaknya, agar tidak mempersekutukan Allah SWT. Q.S. Lukman (31: 13):

$$
\text { وأذ قال لقمن لابنه وهو يعظه يبني لاتشرك }
$$

"Dan (ingatlah) ketika Luqman berkata kepada anaknya, di waktu ia memberi pelajaran kepadanya: "Hai anakku, janganlah kamu mempersekutukan Allah, Sesungguhnya mempersekutukan (Allah) adalah benar-benar kezaliman yang besar." (Q.S Luqman: 13).

Kedua, metode cerita dengan disertai tamsil ibarat dan nasihat, metode ini mempunyai pengaruh terhadap jiwa dan akal. Biasanya anak itu menyenangi tentang cerita-cerita. Untuk itu orang tua sebisa mungkin untuk memberikan masalah cerita yang berkaitan dengan keteladanan yang baik yang dapat menyentuh perasaannya.Sebagaimana firman-Nya dalam QS. al-A`raf (7): 176.

$$
\text { فالقصص القصص لعلهم يتفكرون... }
$$

"... Maka ceritakanlah (kepada mereka) kisahkisah itu agar mereka berpikir".

Ketiga, pengarahan melalui wasiat, Orang tua yang bertanggung jawab tentunya akan berusaha menjaga amanat-Nya dengan memberikan yang terbaik buat anak demi masa depannya dan demi keselamatannya.

\section{Pendidikan dengan Perhatian}

Sebagai orangtua berkewajiban untuk memenuhi kebutuhan-kebutuhan anaknya, baik kebutuhan jasmani ataupun kebutuhan yang berbentuk rohani. Diantara kebutuhan anak yang bersifat rohani adalah anak ingin diperhatikan dalam perkembangan dan pertumbuhannya.

Pendidikan dengan perhatian adalah mencurahkan, memperhatikan dan senantiasa mengikuti perkembangan anak dalam pembinaan akidah dan moral, persiapan spiritual dan sosial, disamping selalu bertanya tentang situasi pendidikan jasmani dan daya hasil ilmiahnya.

Orang tua yang bijaksana tentunya mengetahui perkembangan-perkembangan anaknya. Ibu adalah pembentuk pribadi putra putrinya lebih besar prosentasenya dibanding seorang ayah. Tiap hari waktu Ibu banyak bersama dengan anak, sehingga wajar bila kecenderungan anak lebih dekat dengan para ibunya. Untuk itu ibu diharapkan mampu berkiprah dalam mempersiapkan pertumbuhan dan perkembangan putra-putrinya.

Orang tua yang baik senantiasa akan mengoreksi perilaku anaknya yang tidak baik dengan perasaan kasih sayangnya, sesuai dengan perkembangan usia anaknya. Sebab pengasuhan yang baik akan menanamkan rasa optimisme, kepercayaan, dan harapan anak dalam hidupnya. Dalam memberi perhatian ini, hendaknya orang tua bersikap selayak mungkin, tidak terlalu berlebihan dan juga tidak terlalu kurang. 
Namun perhatian orang tua disesuaikan dengan perkembangan dan pertumbuhan anak.

Apabila orang tua mampu bersikap penuh kasih sayang dengan memberikan perhatian yang cukup, niscaya anak-anak akan menerima pendidikan dari orang tuanya dengan penuh perhatian juga. Namun pangkal dari seluruh perhatian yang utama adalah perhatian dalam akidah.

\section{Pendidikan dengan Memberikan Hukuman}

Hukuman diberikan, apabila metode-metode yang lain sudah tidak dapat merubah tingkah laku anak, atau dengan kata lain cara hukuman merupakan jalan terakhir yang ditempuh oleh pendidik, apabila ada perilaku anak yang tidak sesuai dengan ajaran Islam. Sebab hukuman merupakan tindakan tegas untuk mengembalikan persoalan di tempat yang benar. Hukuman sesungguhnya tidaklah mutlak diberikan. Karena ada orang dengan teladan dan nasehat saja sudah cukup, tidak memerlukan hukuman. Tetapi pribadi manusia tidak sama seluruhnya. Sebenarnya tidak ada pendidik yang tidak sayang kepada siswanya. Demikian juga tidak ada orang tua yang merasa senang melihat penderitaan anaknya. Dengan memberikan hukuman, orang tua sebenarnya merasa kasihan terhadap anaknya yang tidak mau melaksanakan ajaran Islam. Karena salah satu fungsi dari hukuman adalah mendidik. (Elizabeth B. hurlock, 1999: 87). Sebelum anak mengerti peraturan, ia dapat belajar bahwa tindakan tertentu benar apabila tidak menerima hukuman dan tindakan lainnya salah apabila mendapatkan suatu hukuman.

Dalam memberikan hukuman ini diharapkan orang tua melihat ruang waktu dan tempatnya.
Diantara metode memberikan hukuman kepada anak adalah: Pertama, menghukum anak dengan lemah lembut dan kasih sayang. Kedua, menjaga tabiat anak yang salah. Ketiga, hukuman diberikan sebagai upaya perbaikan terhadap diri anak, dengan tahapan yang paling akhir dari metodemetode yang lain.

Memberi hukuman pada anak, seharusnya para orang tua sebisa mungkin menahan emosi untuk tidak memberi hukuman berbentuk badaniah. Kalau hukuman yang berbentuk psikologis sudah mampu merubah sikap anak, tentunya tidak dibutuhkan lagi hukuman yang menyakitkan anak tersebut. Menurut Nashih Ulwan, hukuman bentuknya ada dua, yakni hukuman psikologis dan hukuman biologis.

Bentuk hukuman yang bersifat psikologis adalah: Pertama, menunjukkan kesalahan dengan pengarahan. Kedua, Menunjukkan kesalahan dengan memberikan isyarat. Ketiga, Menunjukkan kesalahan dengan kecaman.

Hukuman bentuk psikologis ini diberikan kepada anak dibawah umur 10 tahun. Apabila hukuman psikologis tidak mampu merubah perilaku anak, maka hukuman biologislah yang dijatuhkan tatkala anak sampai umur 10 tahun tidak ada perubahan pada sikapnya. Hal ini dilakukan supaya anak jera dan tidak meneruskan perilakunya yang buruk. Sesuai sabda Rasul SAW yang diriwayatkan Abu Daud dari Mukmal bin Hisyam. )Abi Daud, 2012: 133)

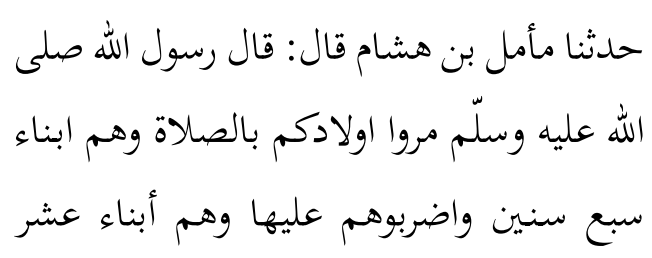


-(وفرقوا بينهم فن المضاجع -(رواه ابو داود

"Surublah anak kalian mengerjakan shalat, sedang mereka berumur tujuh tahun, dan pukullah mereka itu karena shalat ini, sedang mereka berumur sepuluh tahun, dan pisahkanlah tempat tidur mereka". (HR. Abu Daud)

Rasul mengisyaratkan agar memukul anak yang tidak mau melakukan shalat, kata memukul memberikan arti bahwa anak diberikan hukuman agar tidak mengulang perbuatan meninggalkan shalat tersebut. Hal ini jelas bertujuan agar dengan memberikan hukuman kepada anak diharapkan anak dapat patuh menjalankan perintah agama.

\section{KEPUSTAKAAN}

Buku Tarbiyatul Aulad, Pendidikan Anak Dalam Islam mencantumkan 95 buku rujukan, 1 majalah, dan 1 surat kabar.

\section{TENTANG PENULIS}

Abdullah Nashih Ulwan merupakan pemerhati masalah pendidikan terutama pendidikan anak dan dakwah Islam. Nashih dilahirkan di kota Halab, Suriah, tahun 1928. Beliau menyelesaikan studi di sekolah lanjutan tingkat atas jurusan Ilmu Syariah dan Pengetahuan Alam di Halab, tahun 1949. Kemudian melanjutkan di al-Azhar University (Mesir) mengambil fakultas Ushuluddin, yang selesai pada tahun 1952. Selang 2 tahun kemudian, yaitu 1954, ia lulus dan menerima ijazah spesialisasi pendidikan, setara dengan Master of Arts (M.A). Pada tahun yang sama (1954), ia tidak sempat meraih gelar doktor pada perguruan tinggi tersebut, karena diusir dari negeri Mesir oleh pemerintahan Jamal Abdel Naser.
Semenjak ditetapkan sebagai tenaga pengajar untuk materi pendidikan Islam di sekolah-sekolah lanjutan atas di Halab, yaitu tahun 1954, Ulwan juga aktif menjadi seorang da’i. Ulwan termasuk penulis yang produktif, untuk masalah-masalah dakwah, syariah, dan bidang tarbiyah sebagai spesialisnya. Ia dikenal sebagai seorang penulis yang selalu memperbanyak fakta-fakta Islami, baik yang terdapat dalam al-Qur'an, as-Sunnah, dan atsar-atsar para salaf yang saleh terutama dalam bukunya yang berjudul "Tarbiyatul Aulad Fil-Islam. "Hal ini sesuai dengan pendapat Syaikh Wahbi Sulaiman al-Ghawaji al-Albani yang berkata : bahwa dia adalah seorang beriman yang pandai dan hidup.

Diantara karya-karya beliau adalah:

1. Karya yang berkisar pada masalah dakwah dan pendidikan :
a. Al-Takafulul al-Ijtima i Fil-Islam.
b. Ta'addudu al-Zaujat Fil-Islam.
c. Shalahuddin al-Ayyubi.
d. Hatta Ya' lama al-Syabab.
e. Tarbiyatul Aulad Fil-Islam.

2. Karya yang menyangkut kajian Islam (studi Islam) :

a. Ila Kulli Abin Ghayyur Yu'min billah.

b. Fadha' ilul al-Shiyam wa ahkamuhu.

c. Hukmu al-Ta'min Fil-Islam.

d. Ahkamulal-Zakat (4 madzhab).

e. Syubhat wa Rudud Haulal al-Aqidah wa Ashlul al-Insan.

f. Aqabatul al -Zawaj wa thuruqu Mu'alajatiha 'ala Dhanil al- Islam.

g. Mas'uliyatul al-Tarbiyah al-Jinsiyyah. 
h. Ila Waratsatil al-Anbiya .

i. Hukmul al-Islam FI Wasa ilil al-I lam.

j. Takwinu al-Syakh Syiyyah al-Insaniyyah $f i$ Nazharil al-Islam.

k. Adabul =al-Khitbah wa al-Zilaf wa haququl al-Zaujain.

1. Ma'alimul al-Hadharah al-Islamiyyah wa Atsaruha fil al-Nahdhah al-Aurubiyyah.

m. Nizhamul al-Rizqi fil al-Islam.

n. Hurriyatul al-I'tiqad Fil al-Syari ah alIslamiyyah.

o. Al-Islam Syariatul al-Zaman wa alMakan.

p. Al-Qaumiyyah fi Mizanil al-Islam.

\section{DAFTAR PUSTAKA}

'Ali Quthb, Muhammad. (1993). Auladuna fiDlaw-it Tarbiyyatil Islamiyah. Terj. Bahrun Abu Bakar Ihsan. "Sang Anak dalam Naungan Pendidikan Islam”. Bandung: Diponegoro, Cetakan II.

'Isawi, Abdurrahman. (1994). Anak dalam Keluarga. Jakarta: Studia Press, Edisi II.

Ali al-Hasyimi, Muhammad. (2000). The Ideal Muslimah the True Islamic Personality of The Muslim Woman as Defined in The Qur'an and sunnah. Terjemahan oleh Fungky Kusnaedi Timur. "Muslimah Ideal pribadi Islami dalam al-Qur'an dan as-Sunnah". Yogyakarta: Mitra Pustaka, Cetakan I.
at-Tirmidzi, Sunan. (2002). al-Jami'us Sahih. Lebanon: Dar al-Kutbi, Juz IV,

Daud, Abi. (2002). Sunan Abi Daud. Indonesia: Maktabah Dahlan, Juz I.

Depag. RI. (2004). al-Qur'an dan Terjemahnya. Semarang : Toha Putra.

Harun, Salman. (1993). Sistem Pendidikan Islam. Bandung: Ma-arif.

Mubarok al-Barik, Haya Binti. (1988). Mausu'ah al-Mar'atul Muslimah Terjemahan. Amir Hamzah Fachrudin. "Ensiklopedi Wanita Muslimah”. Jakarta: Darul Falah, Cet. IV.

Mushoffa, Aziz dan Musbikin, Imam.(2001) Sepasang Burung dan Nabi Sulaiman. Yogyakarta: Mitra Pustaka, Cetakan I.

Muslim, Imam. (2002). Sahih Muslim. juz IV. Lebanon: Dar al-Kutbi al-Ilmiah.

Nashih Ulwan, Abdullah. (1992). Tarbiyatul Aulad fil-Islam. Terj. Khalilullah Ahmas Masjkur Hakim. "Pemeliharaan Kesehatan Jiwa Anak". Bandung: Remaja Rosdakarya, Cetakan kedua

Tjandrasa, Med.Meitasari. (1999). Perkembangan Anak. Jakarta: Erlangga, jilid II. 